\title{
Is there a Core Curriculum across Higher Education Doctoral Programs?
}

\author{
Karen Card \\ University of South Dakota, \\ Varmillion, SD, USA
}

Karen.card@usd.edu

\author{
Crystal Renée Chambers \\ East Carolina University, \\ Greenville, NC, USA
}

Chambersc@ecu.edu

\author{
Sydney Freeman, Jr. \\ University of Idaho, Moscow, ID, USA \\ Sfreemanjr@uidaho.edu
}

\begin{abstract}
Currently the study of higher education has been referred to as a multidisciplinary field. Consensus is continuing to evolve regarding both what is considered the appropriate coursework and the foundational knowledgebase of this field. The study of higher education is maturing and has the potential to transition from being seen as a field to being respected as an academic discipline. The purpose of the present study is to investigate the status of the core curriculum in higher education doctoral programs from the perspective of program directors with programs that required the completion of standardized coursework prior to beginning a dissertation. We used online survey analytic techniques to query program directors about their EdD and $\mathrm{PhD}$ programs in higher education, credit hours, and curricular content. Our study confirms previous work finding that there is common agreement in the subject matter areas of organization, leadership, administration, and history. What our work adds is that there is a growing consensus among higher education doctoral programs about the position of higher education law and finance in the curricular core. In addition, we find there is a growing interest in public policy and community colleges over time, with a majority of EdD programs including instruction in these areas. Nevertheless, majoritarian agreement does not meet at a level wherein consensus can be inferred, especially within $\mathrm{PhD}$ programs where requirements are more varied across programs. In addition, while there is an increasing trend in the inclusion of multiculturalism in higher education doctoral programming, multiculturalism is not currently part of higher education's core. We conclude with research and practice implications for doctoral programs in higher education as a field of study.
\end{abstract}

Material published as part of this publication, either on-line or in print, is copyrighted by the Informing Science Institute. Permission to make digital or paper copy of part or all of these works for personal or classroom use is granted without fee provided that the copies are not made or distributed for profit or commercial advantage AND that copies 1) bear this notice in full and 2) give the full citation on the first page. It is permissible to abstract these works so long as credit is given. To copy in all other cases or to republish or to post on a server or to redistribute to lists requires specific permission and payment of a fee. Contact Publisher@,InformingScience.org to request redistribution permission.
Keywords: Academic Curriculum, Doctoral Education, Higher Education as a Field of Study

\section{Introduction}

A core curriculum representing the core knowledge and values of a field is necessary to solidify the status as an academic discipline (Bray, 2007; Goodchild, 1991). Consensus around such 
issues as foundational theories and coursework is seen as a sign of a maturing field of study. Currently there is a general consensus that the study of higher education should be categorized as a multidisciplinary field of study, as it draws from well-established disciplines such as, sociology, psychology, business, and history (Goodchild, 2014). However, within the field of higher education, program directors and faculty members identify a lack of agreement on a common knowledge base as an ongoing challenge for higher education graduate programs (Wright \& Miller, 2007). According to Wright (2007), although higher education has made great progress as a specialized field, there is still a "limited amount of research-based teaching materials in higher education" (p. 23) and "no commonly accepted knowledge base" (p. 24). However, now the field is now over 120 years old. This has inspired the authors to reexamine the status of the field and to identify whether it is maturing as evidenced by a consensus of generally accepted coursework. Viewed in that light, coursework represents one measure to gauge academic discipline status.

This study reviews and compares the standard doctorates that offer specializations in higher education studies within the United States, the doctorate of philosophy $(\mathrm{PhD})$ and doctorate of education (EdD). Both types of doctorates in the United States require coursework prior to a person earning this degree. This is different than other countries that offer the general Dr Phil which does not include coursework. This study will focus on the curriculum affiliated with $\mathrm{PhD}$ and EdD programs that offer specializations related to topics within the field of education such as Higher Education and Leadership, Student Affairs, and Community College Leadership. This paper will not be comparing curriculum within and across various disciplines and fields such as the humanities, formal sciences, professions and applied sciences, and brooder social sciences.

The purpose of the present study is to investigate the status of a core curriculum in higher education doctoral programs in programs where a standardized curriculum is required. We do so from the perspective of program directors. Towards that end, we used online survey analytic techniques to query program directors about their degree programs (EdD v. PhD), credit hours, and curricular content. We further inquired if the subject matter or research methods was embedded in the core curriculum, taught as a course, or not included in the core curriculum.

For the purpose of this study, core curriculum is defined as a subject matter or research subjects that all doctoral students are required to learn in a higher education doctoral program. We compared our findings with previous studies by Crosson and Nelson (1986) and Bray (2007). Our study confirms previous work, finding that there is common agreement in the subject matter areas of organizations, leadership, administration, and history. What our work adds is that there is a growing consensus among higher education doctoral programs about the position of higher education law and finance in the curricular core. In addition, we find there is a growing interest in public policy and community colleges over time, with a majority of EdD programs including instruction in these areas. Nevertheless, convergence in subject matter curricular content does not meet at a level wherein consensus can be inferred, especially within $\mathrm{PhD}$ programs. Requirements in higher education $\mathrm{PhD}$ programs vary and this variance gives rise to questions regarding the purpose and aims of those programs. In addition, while there is an increasing trend in the inclusion of multiculturalism in higher education doctoral programming, multiculturalism is not perceived as part of higher education's core. We conclude with research and practice implications for doctoral programs in higher education as a field of study.

\section{Review of Literature}

\section{Prior Studies of Higher Education Doctoral Program Curriculum}

In 1893, G. Stanley Hall offered the first course in what would become the field of study known as higher or tertiary education. That course, college and university problems in the United States 
and Europe focused on the evolving role of colleges and universities in a modernizing world (Goodchild, 1996). Hofsteader (1960) named this era from the 1890s into World War I as the age of reform, and this age did not escape institutions of higher learning. By the 1920s, Hall and colleagues added courses, worked with master's and doctoral students, and created the first graduate program in higher education as a field of study. Today, that field spans 253 master's and 145 $\mathrm{PhD}$, programs worldwide in addition to $75 \mathrm{EdD}$ programs across the United States and United Kingdom, Canada, China, Japan, Australia, and Egypt. Moreover, across 48 nations there are 217 centers and/or institutions devoted to the study of higher and tertiary education (Rumbley, Altbach, Stanfeild, Shimmi, deGayardon, \& Chan, 2014).

Much of the above growth is attributable to the expansion of higher and tertiary education globally, the need to develop leadership, as well as a need to understand trends and respond to a multiplicity of stakeholders in both public and private sectors. Works, such as that of Freeman (2012), Freeman and Kochan (2014), and Haynes (1991) distill competencies needed for higher education leadership from both the perspectives of senior executives in higher education in addition to the vantage of academic scholars. The present work adds to the conversation by presenting surveys of higher education doctoral program curriculum over time.

\section{General Course of Study}

Our approach in the review of curriculum of higher education programs is both a historical and comprehensive. In particular, we thought it important to review how program curricular expectations changed over time among programs that require the completion of coursework prior to beginning a dissertation. The first comprehensive study of higher education programs was conducted by Dressel and Mayhew in 1974. They identified academic administration, student personnel, and community college administration as the most common specializations in early higher education programs in the 1960s. They found a range of requirements that were general in nature and not consistent across programs requirements in education, higher education, research methodology, specialty in higher education, and practicum or internship, a minor within education, a minor or cognate outside of education, foreign language, and dissertation. Most programs required three to six courses in the higher education core which generally included courses in foundations of higher education, student personnel work, community colleges, and administration.

Looking specifically at doctoral level, Dill and Morrison (1985) found in their study of EdD and $\mathrm{PhD}$ programs that research core courses in higher education programs were different only in the number of credits that were required but not in content of the research core courses. They suggested there should be more distinction between what is required in the research core of EdD and $\mathrm{PhD}$ program. In that regard, $\mathrm{PhD}$ programs "should require students to have master's level training in a discipline, including its research courses, and to undergo a research internship in which a research paper based on data collected during the internship is written" (pp. 177-178). EdD programs, in turn, should have research core curriculum that prepares administrators to with research literacy skills and to use data to make better decisions as practitioners. This thought is echoed in Townsend (1990), advancing a view of higher education as not a discipline but as a field that has consequences for the program curriculum. "The primary one is acknowledgement that study in this field is not confined to future scholars and researchers but should also embrace current and would-be administrators who desire training to become more effective practitioners" (p 12). Distinctions between the $\mathrm{EdD}$ and $\mathrm{PhD}$ in higher education doctoral programs are furthered through efforts such as the Carnegie Project on the Education Doctorate (Perry, 2015).

Although research course expectations tend to differ between the $\mathrm{PhD}$ and $\mathrm{EdD}$, core course topics directly related to higher education such as introduction to higher education, higher education administration, finance and budgeting in higher education, and law in higher education have been 
the same (Hyle \& Goodchild, 2014). Therefore in this review we will compare both the doctoral types to investigate if the curricular similarities and differences have remained static overtime.

Regarding curricular content, Crosson and Nelson (1986) conducted a descriptive study of 72 higher education programs. Most frequently offered core courses in these programs were administration/management, general higher education, the history of higher education, and students, which is reflective of the programs' specializations. They concluded that higher education programs appear to be more homogeneous than heterogeneous. In consideration of studies outside of the United States, namely Uzoigwe (1982) and Wang (2002), with some exceptions, one could conjecture that the homogeneity Crosson and Nelson (1986) find in the United States extends more broadly. Uzoigwe in his (1982) dissertation entitled, "A Model for Establishing a Higher Education Administration Degree Program at a Nigerian University", identified the following topics as areas that should constitute the core courses offered at the doctoral and masters level in Nigerian Universities: 1) History and Philosophy of Higher Education (with particular reference to the Nigerian Higher Education System), 2) The Organization and General Administration of Colleges and Universities, 3) Student Personnel Administration, 4) Academic Administration, 5) The Administration of Business and Financial Affairs, 6) General Education, and 7) Institutional Research. The study went on to identify the following as appropriate elective course offerings: 1) Comparative Higher Education, 2) Educational Statistics, 3) Unionism in College and Universities, 4) Higher Education and the Law, 5) Management Information Systems, 6) Continuing Education, 7) Teaching in Colleges and Universities, and 8) Research Seminars. This study was important as it was the first time that a research study had been conducted regarding higher education program curriculum outside of the United States. In 2002 Wang identified that Chinese higher education programs shared core knowledge offerings. Of particular interest were five courses that each of the four programs in the country provided, which included 1) History of Chinese Higher Education, 2) Higher Education Administration, 3) Studies and Foundations of Higher Education, 4) Comparative Education, and 5) Research Methodology in Higher Education.

Bray (2007) made an effort to gain a sense of the core curricula across higher education programs by surveying the administrators of 217 higher education programs affiliated with the Association for the Study of Higher Education (ASHE), but he received only a dearth of survey responses. Instead, he reviewed the programs' websites and was able to find course information for 169 of the 217 programs. Bray (2007) and Harris (2007) both identified limitations in using the webbased approach to studying higher education programs. They both noted that program information collected from websites is not always current nor does it provide thorough explanations of the content or sequencing of courses offered in higher education programs. Nevertheless, Bray (2007) found commonly offered courses that could be considered to represent the core knowledge of the higher education field, especially in these areas: history of higher education, organization and administration, student development/affairs, multiculturalism in higher education, foundations, and philosophy. Hyle and Goodchild's (2014) findings concur that there seems to be trending towards a core emphasis of diversity and inclusion within the field.

Most recently Valerin (2011) conducted a comparative analysis of 105 higher education doctoral programs in the United States, disaggregating the course offerings of $\mathrm{PhD}$ and EdD programs. The study identified that 46 of the programs offered a doctor of education degree and 59 offered the doctor of philosophy degree. The doctor of education degree generally included the following as course offerings: 1) finance of higher education, 2) legal studies, 3) policy studies in higher education, 4) teaching and learning in higher education, 5) research/educational statistics, 6) advanced quantitative research methods, and 7) advanced qualitative research methods. Although these courses were most frequently identified, other courses such as 1) general administration of higher education, 2) history of higher education, 3) philosophy/theory of higher education, and 4) a dissertation seminar. 
Table 1. Prior Studies of Higher Education Doctoral Program Core CurricularContent

\begin{tabular}{|c|c|c|c|c|}
\hline Uzoigwe (1982) & $\begin{array}{c}\text { Crosson \& Nelson } \\
(1986)\end{array}$ & Wang (2002) & Bray (2007) & Vallerin (2011)* \\
\hline $\begin{array}{l}\text { History \& Phi- } \\
\text { losophy of High- } \\
\text { er Education } \\
\text { (Nigerian em- } \\
\text { phasis) }\end{array}$ & History & $\begin{array}{l}\text { History of Higher } \\
\text { Education (Chi- } \\
\text { nese) }\end{array}$ & History & \\
\hline $\begin{array}{l}\text { Organization and } \\
\text { General Admin- } \\
\text { istration }\end{array}$ & $\begin{array}{l}\text { Organization, } \\
\text { Leadership, and } \\
\text { Administration }\end{array}$ & $\begin{array}{l}\text { Higher Education } \\
\text { Administration }\end{array}$ & $\begin{array}{l}\text { Organization, } \\
\text { Leadership, and } \\
\text { Administration }\end{array}$ & $\begin{array}{l}\text { General Administration } \\
\text { of Higher Education } \\
\text { (EdD) }\end{array}$ \\
\hline $\begin{array}{l}\text { Student Person- } \\
\text { nel Administra- } \\
\text { tion }\end{array}$ & Student Affairs & & $\begin{array}{l}\text { Student Develop- } \\
\text { ment }\end{array}$ & $\begin{array}{l}\text { Student Affairs Admin- } \\
\text { istration (EdD)/ } \\
\text { College Student Re- } \\
\text { search (EdD) }\end{array}$ \\
\hline \multicolumn{5}{|l|}{$\begin{array}{l}\text { Academic Ad- } \\
\text { ministration }\end{array}$} \\
\hline $\begin{array}{l}\text { Administration } \\
\text { of Business and } \\
\text { Financial Affairs }\end{array}$ & & & & $\begin{array}{l}\text { Finance of Higher Ed- } \\
\text { ucation }(\mathrm{PhD})\end{array}$ \\
\hline \multicolumn{5}{|l|}{$\begin{array}{l}\text { General Educa- } \\
\text { tion }\end{array}$} \\
\hline \multicolumn{5}{|l|}{$\begin{array}{l}\text { Institutional Re- } \\
\text { search }\end{array}$} \\
\hline & Philosophy & $\begin{array}{l}\text { Studies and } \\
\text { Foundations of } \\
\text { Higher Education }\end{array}$ & & \\
\hline & & $\begin{array}{l}\text { Comparative Ed- } \\
\text { ucation }\end{array}$ & & \\
\hline & & $\begin{array}{l}\text { Research Meth- } \\
\text { odology in High- } \\
\text { er Education }\end{array}$ & & $\begin{array}{l}\text { Research/Educational } \\
\text { Statistics (EdD \& PhD), } \\
\text { Advanced Quantitative } \\
\text { and Qualitative Re- } \\
\text { search Methods (PhD) }\end{array}$ \\
\hline & Faculty & & & \\
\hline & Curriculum & & & $\begin{array}{l}\text { Teaching and Learning } \\
\text { in Higher Education } \\
(\mathrm{EdD}, \mathrm{PhD})\end{array}$ \\
\hline & & & Public Policy & Policy Studies $(\mathrm{PhD})$ \\
\hline & & & $\begin{array}{l}\text { Community Col- } \\
\text { lege }\end{array}$ & \\
\hline & & & & $\begin{array}{l}\text { Legal Studies (EdD, } \\
\text { PhD) }\end{array}$ \\
\hline
\end{tabular}

* Note - courses disaggregated by inclusion in EdD and/ or PhD programs

The doctor of philosophy typically offered these courses according to Valerin's (2011) study: 1) general administration of higher education, 2) legal studies, 3) history of higher education, 4) teaching/learning in higher education, 5) student affairs administration, 6) college student research, 7) research/educational statistics, 8) advanced quantitative research methods and 8) advanced qualitative research methods. Valerin (2011) did not find any statistically significant difference between the numbers of required courses by the doctor of education as compared to the doctor of philosophy. The same results were true regarding the amount of required statistical 
courses. There were no statically significant differences between the two different degree offerings.

In analyzing the literature on higher education doctoral program core curricula, there seem to be some standardized content over time (see Table 1). Courses in organization, leadership, and administration are the most commonly taught as part of the core and that has remained stable over time. History of higher education (with or without philosophy) historically is a staple; however, analysis by Vallerin (2011) could be indicative of changes in the field or are reflective of sampling. There was a growing emphasis on student affairs, student development, and college student research over time. Areas like law and finance which were contained in some core curricula prior to the most recent decades, but also offered as electives, contemporarily were more decisively found as part of the curriculum core (Vallerin, 2011).

\section{Theoretical/Conceptual Frameworks}

To understand the present state of core curriculum in higher education, we draw on Kuhn's (1962) theoretical three-phased process in the development of new sciences. Kuhn's theoretical framework guides this study of the status of higher education core curriculum and assists in the understanding of the field's development into a potential academic discipline. In The Structure of Scientific Revolutions, Thomas Kuhn (1962) described a three-phased process in the development of new sciences and new fields of study. The first phase he calls pre-paradigm, which is marked by the existence of nascent theories that are often incomplete and contradict each other. The second phase is the transition period wherein consensus around core theories and knowledge is developed. The third phase is dubbed "revolutionary science." This phase erupts amid conflict between widely accepted theory and new theories and research. This process is cyclical, and the revolutionary science phase can give way to a new pre-paradigm period. Currently, higher education is arriving towards that second phase but has not yet reached what Kuhn (1962) calls paradigmatic status. Paradigmatic status requires (a) a common set of research problems, (b) a common knowledge base, and (c) a set of commonly accepted research methods. Consensus exists among experts on what people graduating from higher education should be able to do (Crosson \& Nelson, 1986; Miller \& Nelson, 1993). However, an understanding of what higher education graduates should know is not quite firm. The present work inquires into the common knowledge base and research methods. For the explanation and application of Kuhn's (1962) work in the field of higher education see Biglan (1973a, 1973b), Braxton (1989), Braxton and Hargens (1996), Favero (2006), and Smart and Elton (1982).

\section{Research Method}

To answer our overarching research question of what is the commonly taught core curriculum in higher education doctoral programs from the perspective of program directors we used a researcher-designed survey was developed and managed electronically through Survey Monkey®, an online survey firm that specializes in survey development and analysis. The survey is divided in two parts. Part 1 focuses on the subject matter core curriculum, and Part 2 focuses on the research core curriculum. The questions were specific to $\mathrm{EdD}$ or $\mathrm{PhD}$ programs. The survey items were developed through the previous curriculum studies, a review of current program websites, and a critique of the survey items by four program directors. Given previous studies related to this topic there is a sizeable number of $\mathrm{PhD}$ and $\mathrm{EdD}$ programs in the field of higher education which have a set of core courses that each student in the program must complete successfully prior to commencing the dissertation. Therefore, we were comfortable in asking the questions below regarding the core curriculum. Program directors were asked the following questions:

1. What subject matter were all doctoral students required to learn in the higher education program? 
2. What research subjects were all doctoral students required to learn in the higher education?

3. How was the subject matter or research methods taught in core curriculum?
a. Embedded in existing core courses?
b. Taught as a course?
c. Not included in the core curriculum?

As the survey was designed, program directors could click boxes to identify courses and how subjects were taught, whether embedded, as a course focal point, or not included. As in prior studies, this study was exploratory and descriptive in nature, with a purpose to describe what subject matter or research topics are included in the core curriculum of higher education doctoral programs. Given the exploratory nature of this study, hypothesis testing is inappropriate. Nevertheless, comparison of our work with the previous research of other scholars gives a sense of the development of core knowledge in the field over time. In addition, this work would not be appropriately classified as qualitative in nature as the inquiry is positivistic rather than interpretivist in design.

Directors of the 132 doctoral programs identified from the Association for the Study of Higher Education (ASHE) directory were sent an email through Survey Monkey ${ }^{\circledR}$, asking them to participate in this study. Fifteen program directors had previously indicated that they did not want to participate in Survey Monkey® surveys so surveys were sent to the remaining 117 program directors. Two program directors responded that their program no longer existed. Of the 115 program directors who had programs and were willing to complete the survey, 44 responded $(38.2 \%)$. Within the social sciences, a 30\% response rate is sufficient for survey validity (Van Horn, Green, \& Martinmussen, 2009). Nineteen programs (43.2\%) participating offer both an EdD and $\mathrm{PhD}$. Another 16 programs offer only the $\mathrm{EdD}(36.4 \%)$ and nine programs offer only the $\mathrm{PhD}(20.5 \%)$. See Table 2.

Table 2. Type of Doctoral Programs Offered

\begin{tabular}{lll}
\hline Program Types & N & \% \\
\hline Both PhD and EdD & 19 & 43.2 \\
EdD & 16 & 36.4 \\
PhD & 9 & 20.5 \\
\hline
\end{tabular}

In reporting the results of this study, the findings are compared to previous studies by Crosson and Nelson (1986) and Bray (2007) to identify any trends and changes in the core curriculum of higher education over time. These studies were selected as there is significant overlap among programs sampled, which provides some consistency for descriptive trends analyses. We identify as part of the core curriculum those courses in which $66 \%$ or more of respondent programs require a given subject matter. A two-thirds majority seems a fitting benchmark given the level of variation among programs. In addition, in no prior study has that benchmark been met, which is part of the justification of this study: the inability to identify a common knowledge core in higher education doctoral programs (Wright \& Miller, 2007). We identify as emergent core those courses where between $50 \%$ and $65 \%$ of programs require a given subject matter and there is an upward trend in the requirement of the given course from Crosson and Nelson (1986) and Bray (2007) to the present study. We identified subject matter courses as descendent (trending towards being offered less in the future). 


\section{Results}

\section{Subject Matter Core Curriculum}

History of higher education and a course in organization, leadership, and administration are two subject matters consistently taught as courses in the core curriculum of higher education programs in this study and in previous studies (Bray 2007; Crosson \& Nelson, 1986; see also Uzoigwe, 1982; Vallerin, 2011; Wang, 2002). However, law and finance are becoming ever more present as higher education core curriculum. Trends from Crosson and Nelson (1986), Bray (2007) and the present study are presented in Figures 1 and 2. Data presented is organized by course across studies. As data collection varied across studies, we do not have complete information for the presence of particular studies across all studies and there are empty rows (white spaces) where data is not available. In addition, we delineate between $\mathrm{EdD}$ and $\mathrm{PhD}$ programs as did Bray (2007). Crosson and Nelson (1986) analyses were of doctoral programs more broadly.

\section{Core courses}

History of higher education is a commonly taught core course in both $\mathrm{EdD}(\mathrm{n}=27,77 \%)$ and $\mathrm{PhD}$ $(\mathrm{n}=19,68 \%)$ programs. However, it is the only course meeting at a core curriculum status as a standalone course across both $\mathrm{EdD}$ and $\mathrm{PhD}$ programs. Among EdD programs, three additional courses can be considered as part of the knowledge core and are taught as separate courses. They are organization, leadership, and administration $(n=24,69 \%)$, legal aspects or law $(n=28,80 \%)$, and higher education finance $(n=26,74 \%)$. Legal aspects or law $(n=18,64 \%)$ and higher education finance $(\mathrm{n}=17,60 \%)$ are part of an emergent core in $\mathrm{PhD}$ programs. For both $\mathrm{EdD}$ and $\mathrm{PhD}$ programs, the prominence higher education of finance has grown by a factor of approximately $20 \%$ from Crosson and Nelson (1986) to Bray (2007) and an additional 30\% from Bray (2007) to the present study. A progression in law/ legal aspects seems similar; however, as data were not collected in Bray (2007) on this course, a definitive trend seems unclear.

With respect to organization, leadership, and administration in $\mathrm{PhD}$ programs, there seems to be a descendent trend. Whereas there was a 20\% increase in identified required core coursework from Crosson and Nelson (1986) to Bray (2007), reaching the 66\% mark for the PhD in Bray, in the present study only $54 \%$ of $\mathrm{PhD}$ programs $(\mathrm{n}=15)$ require the course. Another $29 \%$ of PhD programs $(\mathrm{n}=8)$ embed this material in other courses. With the exception of $1 \mathrm{PhD}$ program, all higher education doctoral programs require attention to this subject matter. As such this subject matter can be considered as core across higher education doctoral programs, although the mode of delivery, standalone course or embedded, varies. See Figures 3 and 4.

As depicted in Figures 3 and 4, the authors attempted to glean whether course contents were taught in standalone courses, subject matter embedded in other courses, or content that was not included within the course of study. Problematics with this measure are discussed in the limitations section. Figure 2 depicts for EdD programs, Figure 3 for PhD programs. In EdD programs, history, law, finance, and organizations content was taught through standalone coursework at levels demarking core curriculum (66\% or higher). History of higher education and law are the only two content areas taught as standalone courses in more than $60 \%$ of programs. Finance is taught as a standalone course in $60 \%$ of programs, organizations in $54 \%$. 

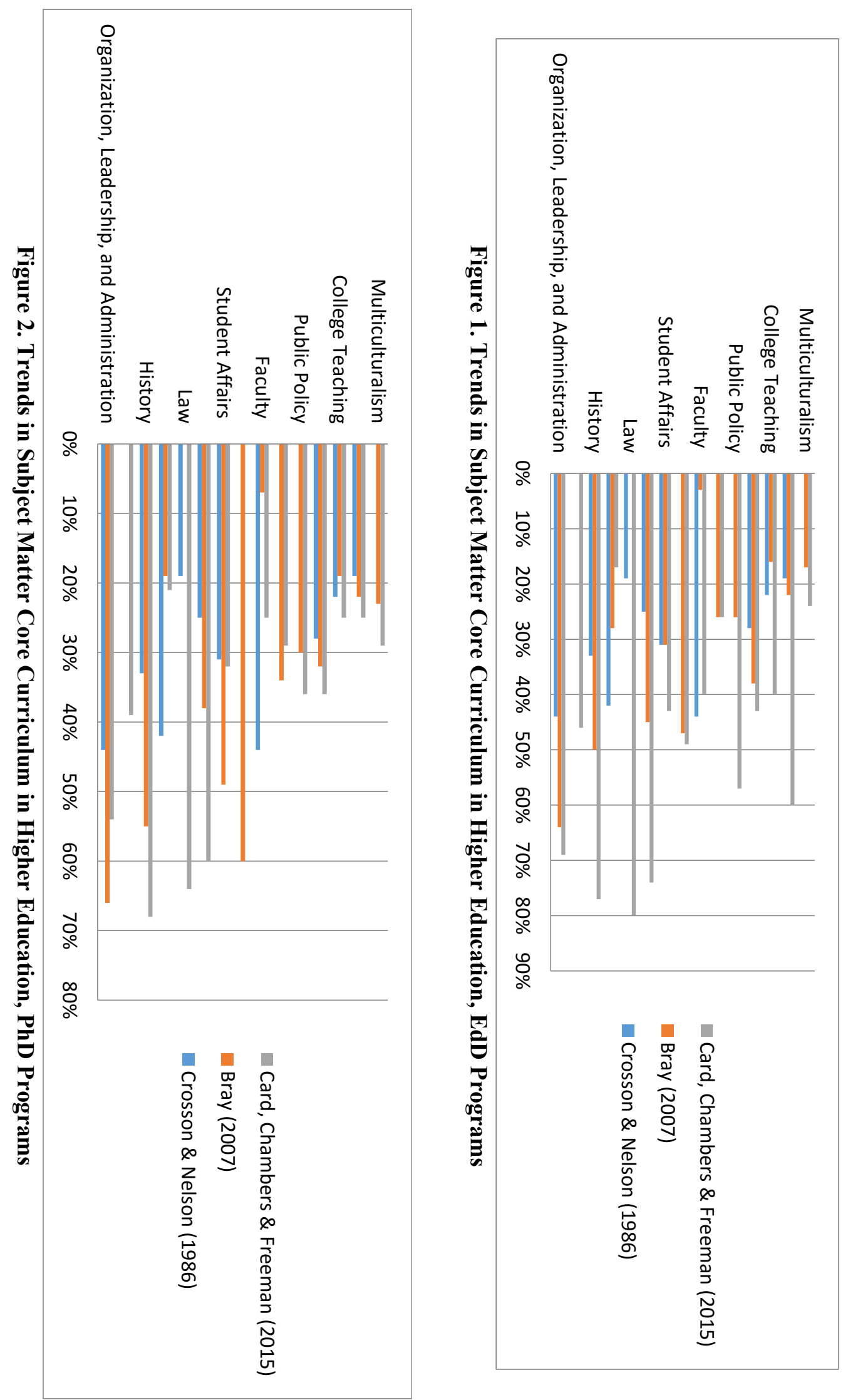

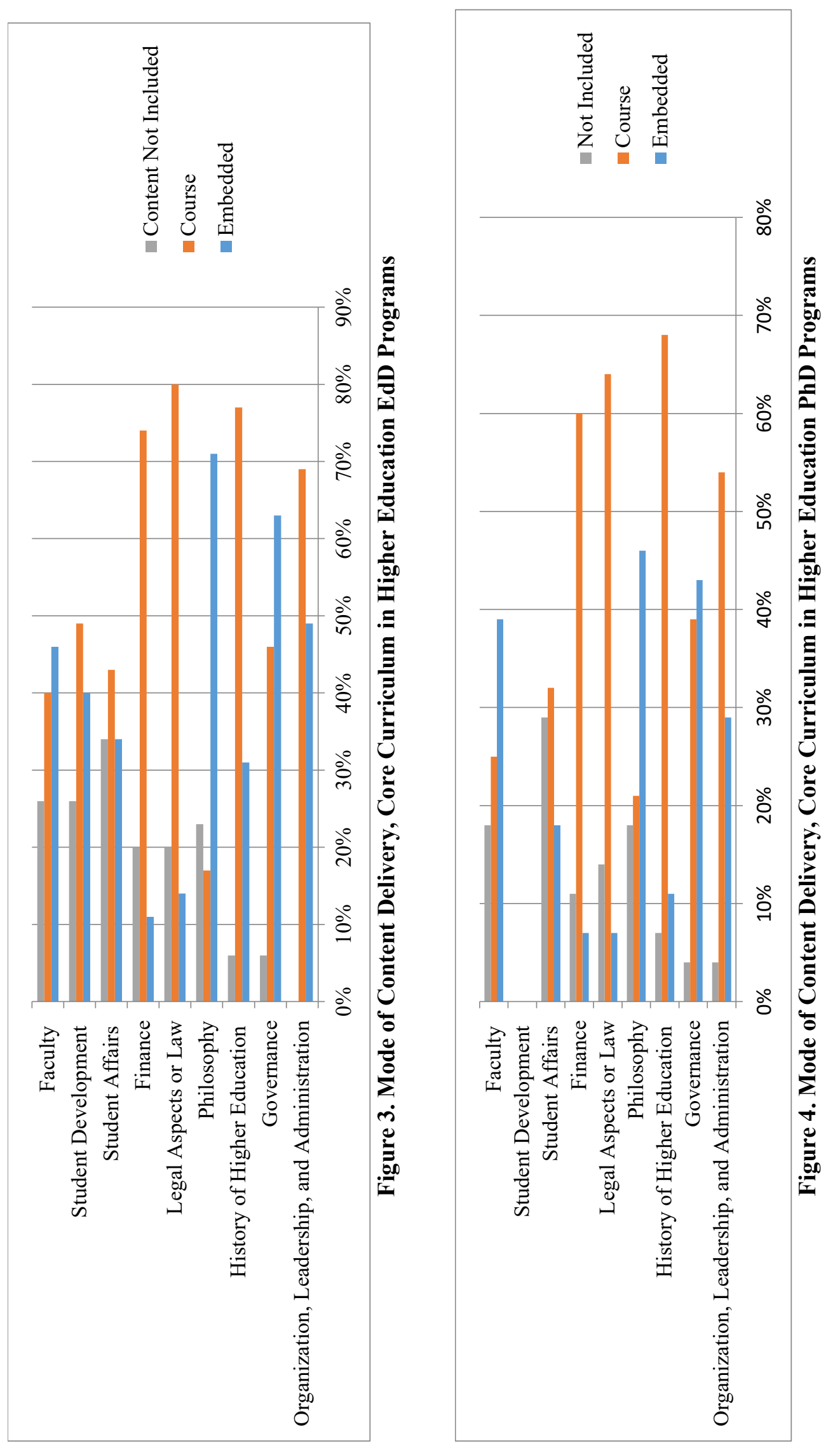
It is clear from the figures above that curriculum in the areas of history, law, finance, and organizations are commonly taught as standalone courses. Additionally, within EdD programs there is an emergent core growing in the areas of public policy and the community college. Public policy is required more frequently as a core course in this study than in prior studies. In EdD programs, $57 \%$ required a course in public policy $(n=20)$ and $43 \%$ of programs report embedding public policy content in other courses $(\mathrm{n}=15)$. Crosson and Nelson (1986) did not collect data on this course, but in Bray (2007) only $26 \%$ of EdD programs required public policy as part of their core. Interestingly, in Bray (2007) more $\mathrm{PhD}$ than EdD programs required public policy. In the present study, only $36 \%$ of $\mathrm{PhD}$ programs $(\mathrm{n}=10)$ required the coursework. With respect to the community college, $60 \%$ of EdD programs require coursework as part of the core $(n=21)$. Twenty-three percent embed this subject matter. In both Crosson and Nelson (1986) and Bray (2007), about $20 \%$ of programs included this coursework, an indicator of substantial growth, at least within EdD programs. In $\mathrm{PhD}$ programs, the percentage remains stable at $25 \%(\mathrm{n}=7)$. The same percentage of $\mathrm{PhD}$ programs does not include community college content at all.

Almost half of all undergraduate students in the United States are educated in community colleges (AACC, 2015a) and this added emphasis on the community college may reflect both those trends as well as federal efforts highlighting the role of community colleges (AACC, 2015b). Globally, post-secondary education outside of traditional colleges and universities is a growing option for many people to build the skills necessary for knowledge and service based economies. Introducing doctoral candidates to this context as well as program specializations devoted to community college and technical education is important for continued leadership in these organizations.

A core course in student affairs is required in less than half of the programs in this study. Among EdD programs 15 (43\%) required this coursework. Among PhD programs the percentage was lower at $32 \%(n=9)$. This subject matter is not included in the core curriculum either as a course or embedded by an almost equal number of programs (EdD $n=12$ [34\%]; PhD n= 8[29\%]) (See Figures 1 and 2). These findings are similar to Bray (2007) with Crosson and Nelson (1986) finding even fewer programs with this coursework as part of their core. Thus, while there may have been some growth in these courses over time, that growth in this snapshot looks stunted. It may be the case that coursework in student affairs including courses in student development theory, student affairs, and student services is being offered in more specialized programs aimed at student affairs personnel.

\section{Embedded content}

We found philosophy, governance, and multiculturalism as more embedded in other core courses than taught as a separate core course. Philosophy can be considered as part of this core in EdD programs, but as content that is taught embedded within another course, such as history. Philosophy content is embedded in $25(71 \%)$ of the EdD program core curriculum, with $13(46 \%) \mathrm{PhD}$ programs embedding it in their $\mathrm{PhD}$ program. This difference is curious as a doctorate of philosophy would seem to lend itself towards greater immersion in philosophical content. Only 6 EdD and $6 \mathrm{PhD}$ programs offer philosophy as a core course, $17 \%$ and $21 \%$ of respondent programs respectively. These findings are similar to those of Crosson and Nelson (1986) and Bray (2007). It is also interesting to note that education foundations is taught in one-third or fewer programs. In our study, $9 \mathrm{EdD}$ programs (26\%) and $8 \mathrm{PhD}$ programs (29\%) offered education foundations as part of their core. Data was not collected on this course in Crosson and Nelson (1986); however, Bray's (2007) findings were similar with respect to the EdD and slightly higher in the PhD. Future work could identify whether this is indeed a downward trend.

Content in higher education governance is also seen as core content in EdD programs, but as embedded within other courses. Like in EdD programs, philosophy and governance content is more 
likely to be taught as content embedded within another course. Governance is embedded in the core curriculum of EdD programs at a rate indicative of an emergent trend: $63 \%(n=22)$. Fortythree percent of EdD programs $(n=12)$ embed governance content, and only two respondent EdD programs did not offer governance content as part of their core. Data was not collected on this subject matter in either Crosson and Nelson (1986) or Bray (2007), so we cannot delineate any trend. In PhD programs, governance content is offered almost equally between embedded ( $43 \%$, $\mathrm{n}=12)$ and separate required core courses $(39 \%, \mathrm{n}=11)$.

Multiculturalism is embedded in the core curriculum of $23 \mathrm{EdD}$ programs $(66 \%)$ and meets at the level of an emergent trend. Bray (2007) documented 17\% of programs with a multiculturalism course; however, due to the web based design of his study, he could not ascertain whether this subject matter was taught embedded in other courses. In PhD programs, only 10 (44\%) programs embed multicultural content and even fewer offer it as a standalone course $(n=8,29 \%)$. It tends not to be taught as a separate course in the core curriculum. The inclusion of multiculturalism coursework as identified in our study and in Bray's may indicate a need for curricular content devoted towards building the multicultural competence of higher education doctoral students. That said, it may be that programs are struggling with where to add this content as part of the curricular core and embedding may be a viable solution. In the alternative, it may be the case that this work is being offered at the master's level and students at the doctoral level have a baseline of familiarity. That said, multicultural competence is a life long journey, not a destination (Pope \& Reynolds, 2004). Future work should assess the efficacy of embedded multicultural content on multicultural competence building among higher education doctoral students.

Overall, there is less consensus across $\mathrm{PhD}$ programs regarding core curriculum whether delivered through standalone courses or as content embedded within other coursework. EdD programs tend to be more prescriptive in the number of subject matter core credit hours required with $42.1 \%(n=16)$ programs requiring 22 hours or more of subject matter core curricula. On average EdD programs require 16-18 hours. Variation among $\mathrm{PhD}$ programs is wider and the distribution is bimodal with $28 \%$ of programs $(n=7)$ requiring 22 or more hours and another $28 \%$ requiring 13 to 15 hours of core. The 13 to 15 hour range is the median (See Table 3). Overall, there is no statistically significant difference in the number of subject matter core requirements between EdD and $\mathrm{PhD}$ programs $(t=1.12, p>0.05)$.

Table 3. Number of Credits Required, Subject Matter and Research Core Curriculum

\begin{tabular}{|c|c|c|c|c|c|c|c|c|c|}
\hline \multicolumn{3}{|c|}{ Research Core } & \multicolumn{7}{|c|}{ Subject Core } \\
\hline & Ed & & PhI & & & Edl & & $\mathbf{P h}$ & \\
\hline \# of Credits & $\mathbf{N}$ & $\%$ & $\mathbf{N}$ & $\%$ & \# of Credits & $\mathbf{N}$ & $\%$ & $\mathbf{N}$ & $\%$ \\
\hline$<6$ & 2 & 7 & 0 & 0 & $\leq 9$ & 1 & 2.6 & 1 & 4.0 \\
\hline 6 & 2 & 7 & 1 & 4 & $10-12$ & 4 & 10.5 & 4 & 16.0 \\
\hline 9 & 6 & 21 & 0 & 0 & 13-15 & 10 & 26.3 & 7 & 28 \\
\hline 12 & 12 & 39 & 6 & 26 & $16-18$ & 5 & 13.2 & 3 & 12.0 \\
\hline \multirow[t]{2}{*}{$15+$} & 7 & 25 & 16 & 70 & $19-21$ & 2 & 5.3 & 3 & 12.0 \\
\hline & & & & & $22+$ & 16 & 42.1 & 7 & 28.0 \\
\hline
\end{tabular}

\section{Research Core Curriculum}

Introductory coursework in qualitative research methods meets at the level of core curricula in EdD programs $(n=24,69 \%)$ and emergent core in $\mathrm{PhD}$ programs $(n=18,64 \%)$. This course is the one most often taught as part of the research core across $\mathrm{EdD}$ and $\mathrm{PhD}$ programs. Introductory quantitative research methods meets at the emergent trend level in EdD programs with $57 \%$ of programs $(\mathrm{n}=20)$ offering this course as part of their research core. $\mathrm{PhD}$ programs were less likely to offer introductory quantitative research coursework ( $n=7,25 \%$ ) (See Figures 5 and 6). 
Advanced quantitative experimental methods and correlational methods were taught most often as core research courses in $\mathrm{PhD}$ rather than in EdD programs. Experimental design is taught in $61 \%(n=17)$ of PhD programs reporting and $41 \%(n=17)$ of EdD programs. Correlational methods are taught in $15(54 \%) \mathrm{PhD}$ programs and 14 (40\%) EdD programs. In this vein, advanced quantitative research coursework in experimental and correlational analysis meets at the emergent core level in $\mathrm{PhD}$ but not EdD programs. Future work should ascertain student access to higher levels of statistical analyses such as structural equation modeling and hierarchical linear analysis, especially in $\mathrm{PhD}$ programs. In addition, more information about advanced qualitative research training should be gathered.

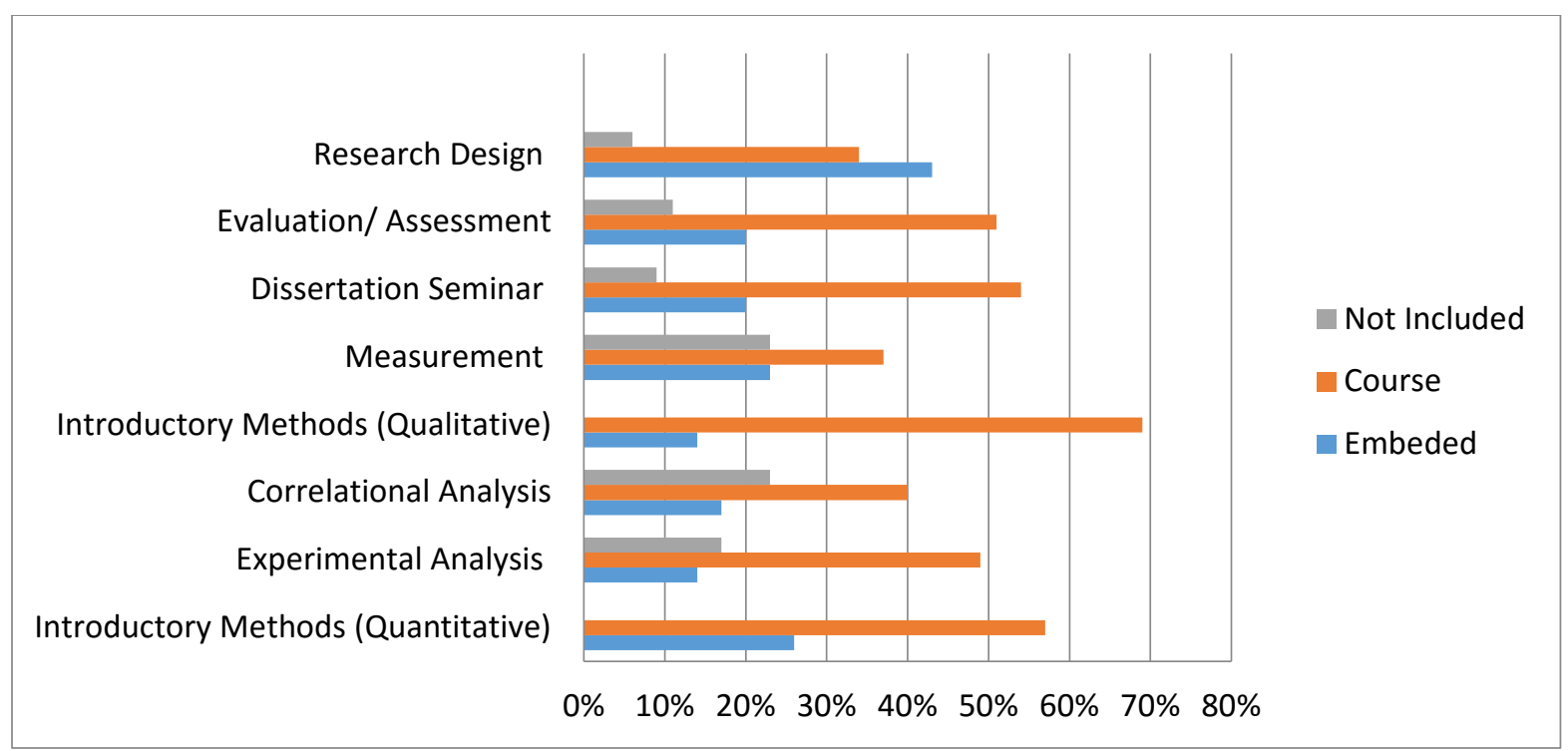

Figure 5. Research Core Curriculum in EdD Programs

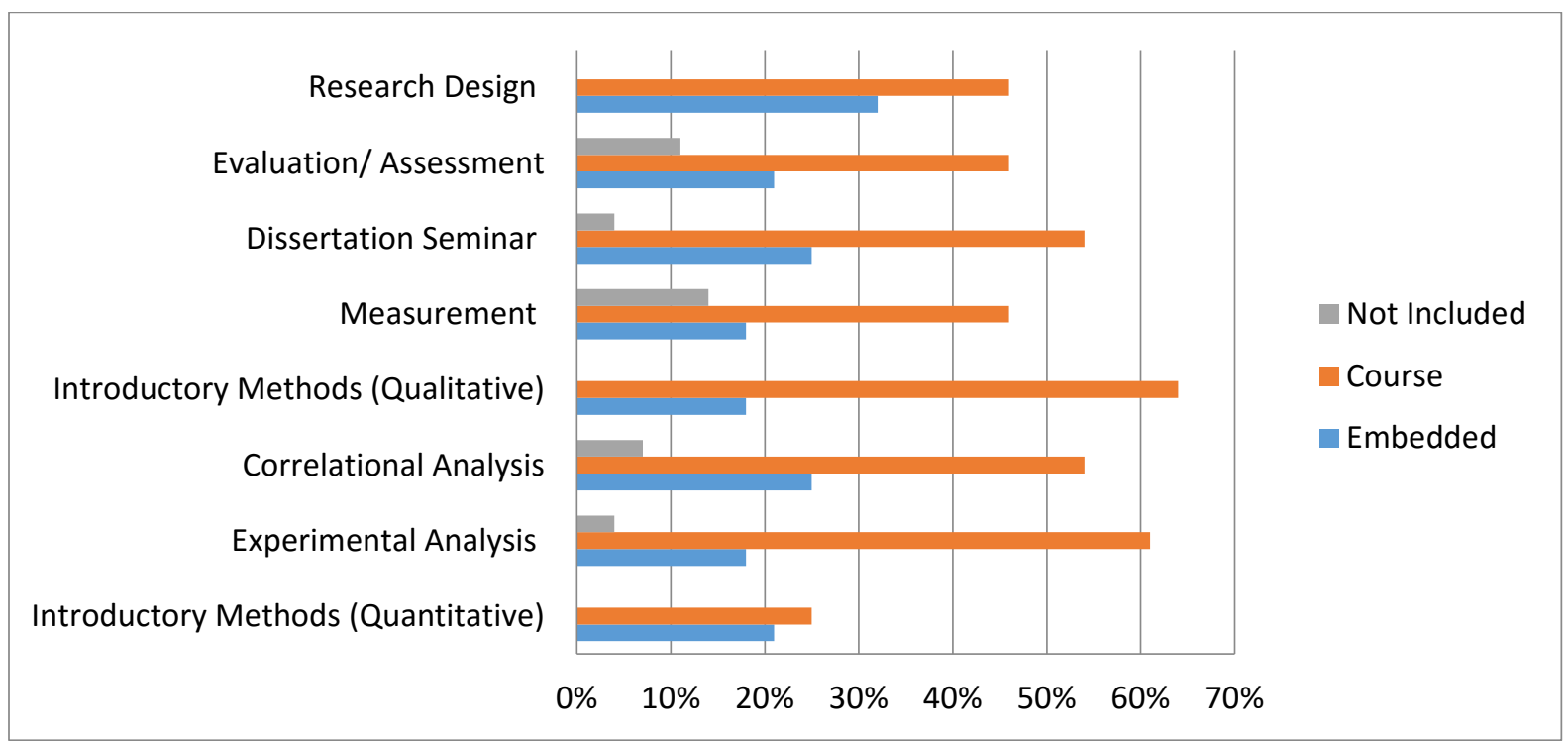

Figure 6. Research Core Curriculum in EdD Programs

Other research courses taught as part of the core were dissertation seminars emphasizing the development of dissertation problems and proposals, courses in evaluation and assessment, as well as courses in measurement, instrument construction and design were also reported. Dissertation seminars were taught in $54 \%$ of programs $(n=19, \mathrm{EdD} ; \mathrm{n}=15, \mathrm{PhD})$. Courses in evaluation and 
assessment were taught in $18(51 \%)$ EdD programs and $13(46 \%) \mathrm{PhD}$ programs. Given the applied practitioner focus of EdD programs, it makes sense that they would be more likely to require evaluation and assessment as part of their core. However, the difference between EdD and $\mathrm{PhD}$ programs perhaps should be greater to reflect program differentiation. Measurement topics (reliability, validity, and item analysis) were more often taught as a core in $\mathrm{PhD}$. programs $(\mathrm{n}=13$ [46\%]), but that difference is small. Thirteen EdD programs (37\%) reported courses in measurement topics. Research design was more often embedded in other research core courses in EdD programs ( $\mathrm{n}=15$ [43\%]), but taught as its own course in $\mathrm{PhD}$ programs $(\mathrm{n}=13$ [46\%]). But this difference also is slight (See Figures 5 and 6).

More significant than the differentiations among the research courses and content taught in EdD and $\mathrm{PhD}$ programs, there is a significant differentiation in the number of research courses taught (See Table 3). The bulk of EdD programs (39\%) require 12 credit hours in the research core, whereas the gross majority $(70 \%)$ of $\mathrm{PhD}$ programs require 15 credit hours or more. In addition there was wider variance among EdD programs $(\mathrm{M}=3.59$, S.D. $=1.12)$ than $\mathrm{PhD}$ programs $(\mathrm{M}=4.61, \mathrm{~S} . \mathrm{D} .=0.72)$ in the number of hours required. This difference is statistically significant $(t=-3.868, p \leq 0.0001)$.

\section{Discussion}

The purpose of this study was to investigate the status of the core curriculum in higher education doctoral programs from the perspective of program directors in an effort to identify if there was a common core curriculum used across programs. Unfortunately the response rate to the online survey in this study was not as high as was expected. However, many of the findings for this study are consistent with previous studies that identified common courses that could be determined as core curriculum for higher education programs.

Courses in the history of higher education and organization, leadership, and administration are two courses that have been consistently identified as core courses in higher education programs (Bray 2007; Crosson \& Nelson, 1986; Uzoigwe, 1982; Vallerin, 2011; Wang, 2002). Of especial interest here is the relative difference in the prominence of organization, leadership, and administration coursework between $\mathrm{EdD}$ and $\mathrm{PhD}$ programs. It appears from this study and previous studies that common knowledge based in higher education doctoral programs is organization, leadership, and administration which may be the paradigm of higher education programs (Kuhn, 1962). However, we notice a flux, a descendant trend here, although the trend in history seems more stable, more paradigmatic. More in-depth study of organization, leadership, and administration, such as content analysis of syllabi and qualitative interviews with faculty who teach this course, is needed to better understand the theories knowledge base from which organization, leadership and administration are taught (Bray, 2007).

The present study's most significant addition to the literature on higher education doctoral programs is the increasing prominence of legal aspects or law courses and finance courses as part of the core curriculum of most programs. The percentages are higher percentages than in previous studies (Bray, 2007; Crosson \& Nelson, 1986; Valerin, 2011) and meet at the level of core curriculum in EdD programs, emergent core in $\mathrm{PhD}$ programs. In an age of increasing accountability, accreditation oversight, and connections between accreditation and institutional fiscal health, the knowledge of finance may have become more important for administrators to learn. Regulatory aspects of law, as well as an understanding of employment law, discrimination, and student constitutional rights may to be of increasing import. A current example of prominence is that of the increase in sexual assault reporting on American (U.S.) campuses, and the observation that many campuses are ill equipped to conduct investigations, counsel students, or manage crises (Lipka, 2014). In this vein, a knowledge foundation in due process and regulatory procedure is of increasing significance to practitioners. 
That governance, philosophy, and multiculturalism are more embedded in the core curriculum than taught as separate core courses has interesting implications for higher education programs and their graduates. The focus on governance, even if embedded, may be connected to the increasing prominence of courses in law and finance. With respect to multiculturalism, given the growing emphasis on multicultural competencies, program faculty may wish to discuss the role this subject area should have in the core curriculum (Hyle \& Goodchild, 2014). In addition, it would seem that PhD programs advancing scholarly knowledge in the field of higher education would better serve their students with a stronger emphasis in philosophy and education foundations.

With respect to core subject matter curriculum, there is a discernable core/emergent core in EdD programs, but not in PhD programs. As identified in the Council for Higher Education's Proposed Doctoral Guidelines, coursework in the history of higher education; finance; organization, leadership, and administration; and law are central to an understanding of higher education as a field of study, a foundation for higher education practitioners and perhaps higher education scholars as well (Council for the Advancement of Higher Education Programs, 2015). Further study is needed into the nature and focus of higher education $\mathrm{PhD}$ programs to understand their purpose and how they prepare students. $\mathrm{PhD}$ programs may benefit from identifying an organizing principle for their curriculum (Townsend, 1990). Hendrickson's (2014) core knowledge taxonomy may be helpful towards this end.

A core curriculum in research is easily visible in higher education programs. Introductory courses in quantitative methods and qualitative methods followed by advanced quantitative methods and dissertation seminars emphasizing the development of a dissertation problems and proposals are offered in the research core of most programs. Courses in evaluation and assessment are taught in both degree programs which again may reflect programs preparing administrators for higher education. The major difference between $\mathrm{EdD}$ and $\mathrm{PhD}$ research course requirements appears to be in the number of credits offered and not the content which is similar to the findings in Dill and Morrison's (1985) study.

As paradigmatic status requires (a) a common set of research problems, (b) a common knowledge base, and (c) a set of commonly accepted research methods, the fact that there is a set of common research topics taught in both in $\mathrm{EdD}$ and $\mathrm{PhD}$ programs demonstrated that the study of higher education meets the requirement of Kuhn's (1976) paradigmatic status. Nevertheless, there are questions as to whether there sufficient differentiation aligned with program goals (Dill \& Morrison, 1985; Lattuca \& Stark, 2011). With respect to curricular content, there seems to be a solid emergent core impinging towards paradigmatic status, at least in the EdD. What appears to missing is an agreement on core curricular content $\mathrm{PhD}$ programs. Across the board, future work can confirm whether there is a common set of research problems in the higher education field.

\section{Limitations and Delimitations of the Study}

The low response rate to the online survey is a limitation of this study. While a rate of $38.2 \%$ is sufficient for a preliminary inquiry, and the absolute numbers of respondents are in line with prior studies, a higher response is needed to garner a better sense of the field. Researchers plan to follow up with a mailed paper survey to programs that did not respond to the email survey. In addition there are some issues with regards to the internal validity of the survey. Three program directors emailed the researcher to share aspects of the survey they found confusing, such as what defined core curriculum and what the difference was between an embedded and a free-standing course, which may have influenced the response rate and/or the results. Moreover, future work should endeavor to include the perspectives of more programs globally given the proliferation of programs internationally. 
A delimitation of this study is that we did not inquire into curricular content beyond course titles, such as what is meant by or what are the subject matters covered in courses in governance, organizational theory, history of higher education, and the like. While Crosson \& Nelson (1986) and Miller \& Nelson (1993) identify consensus about what higher education graduates should be able to do post-graduation, future work should assess congruence between those program outcome benchmarks and core curriculum.

\section{Conclusion}

Contemporary higher education research published in journals, including but not limited to the Journal of Higher Education, The Review of Higher Education, and Research in Higher Education, in addition to research generated through doctoral dissertations and theses, will further the knowledge base of higher education as a field of study. However, core curricula embodies essential theories, philosophies, and commonly held understandings as well as holding the memories of why a field develops through its history and provides continued justification for the field's existence. It also provides the linguistic core, the language contemporarily spoken by researchers and practitioners. In the classroom, the core curriculum is the knowledge base passed from one generation to the next. Having a defined core is a necessary, albeit not sufficient, predicate towards developing higher education, a multi-disciplinary field of study into an academic discipline, with a stand-alone knowledge base as supplemented by the social sciences and allied professional fields.

In the present study, we find there is a commonly used subject matter core curricula among EdD programs encompassing coursework in the history of higher education, organizations, administration and leadership, law and finance as well as embedded course content in the areas of philosophy, governance, and to a lesser extent multiculturalism. In terms of an emergent core, public policy and community college seem to be of increasing importance in EdD programs which stands to reason given the importance of both of these areas for students. The majority of all college students in the U.S. are community college students as are a large share of the jobs in higher education administration. It is important to ensure that students who are preparing for careers in the community college have an understanding of that context. In addition, for students in the four year sector, knowledge of the community college contexts can help as one designs policies, procedures, and supports for students transferring from the community college context. With respect to public policy, declining funding for public higher education and increasing demands for accountability create contexts where higher education doctoral graduates need an awareness of policy changes and the influence of those changes on their practice. Beyond awareness, doctoral programs can give students tools to address policy makers and direct research efforts that can be influential in educating lawmakers at the state and national levels.

With respect to $\mathrm{PhD}$ programs, variation is more widespread, reflecting differential purposes between $\mathrm{EdD}$ and $\mathrm{PhD}$ programs. History and organizations are the most common courses core subject matter required of $\mathrm{PhD}$ students. Surprisingly, given that a $\mathrm{PhD}$ is a doctorate of philosophy, philosophy is not part of the embedded core. While $\mathrm{PhD}$ programs still require coursework, they tend to be less prescriptive, perhaps giving more freedom to individual students to craft their individual courses of study. This approach to $\mathrm{PhD}$ work seems closer to European models where students engage in independent study to better hone in their individual areas of expertise. By implication, it seems the purpose of doctoral education in $\mathrm{PhD}$ programs is more directed towards equipping scholars than preparing practitioners. Towards this end, our finding in the absence of content in the area of philosophy is a point of concern as $\mathrm{PhD}$ students may not be exposed to different traditions of philosophical thought and how those traditions are connected to research methods, scholarship, and higher education policy. 
There are no differences in the number of subject matter course credits required between EdD and $\mathrm{PhD}$ programs. However, there is a difference with respect to research, with $\mathrm{PhD}$ programs requiring both more hours and content more focused on specific areas of statistical design (e.g., measurement, correlational, and experimental design). This makes sense as $\mathrm{PhD}$ programs are more oriented towards the development of scholars. Future research should probe the course of research methods best suited to equip EdD candidates as practitioners.

From the present study we cannot delineate a common core for research methods at either the $\mathrm{EdD}$ or PhD level. The one course commonly taught, regularity of instruction meeting at the level of emergent core, is introductory qualitative methods. It is likely the case that within prior coursework at the undergraduate and master's levels students are given access to basic concepts in quantitative research methods. However, for qualitative research methods, data collection, and analysis, students are less likely to have access until coursework at the doctoral level. As doctoral education is the most advanced degree offered by colleges and universities, it stands to reason that introductory coursework, including qualitative research methods, are offered earlier within a student's academic career.

In an age of increasing accountability and competing demands it is important that doctoral candidates are well prepared to conduct research, as well as navigate policy and procedural terrain. This speaks to differentiations between EdD and PhD coursework. Nevertheless, future work should explore beyond core subject matter by course title and evaluate actual content within courses, perhaps by way of syllabi analyses and/or interviews with program coordinators. In addition, outcomes based analyses, connecting the subject matter and research core to competencies, and demonstrated practical and theoretical content knowledge by doctoral graduates is needed to ascertain the difference made in colleges and universities. The present work contributes to our understandings of the differences between $\mathrm{EdD}$ and $\mathrm{PhD}$ programs as well as helps coalesce understandings of subject matter core curriculum, especially with in the EdD context.

\section{References}

AACC. (2015a). Community college trends and statistics. American Association of Community Colleges (AACC). Washington, D.C. Retrieved from http://www.aacc.nche.edu/AboutCC/Trends/Pages/default.aspx

AACC. (2015b). 21st Century initiative. American Association of Community Colleges (AACC). Washington, D.C. Retrieved from http://www.aacc.nche.edu/AboutCC/21st_century/Pages/default.aspx

Biglan, A. (1973a). The characteristics of subject matter in different academic areas. Journal of Applied Psychology, 58, 195-203.

Biglan, A. (1973b). Relationships between subject matter characteristics and the structure and output of university departments. Journal of Applied Psychology, 57(3), 204-213.

Braxton, J. M. (1989). Institutional variability in faculty conformity to the norms of science: A force of fragmentation in the academic profession? Research in Higher Education, 30(419), 433.

Braxton, J. M., \& Hargens, L. L. (1996). Variations among academic disciplines: Analytical frameworks and research. Higher Education: Handbook of Theory and Research, 11,1-45.

Bray, N. J. (2007). Core curriculum for American higher education programs. In D. W. Wright \& T. Miller (Eds.), Training higher education policy makers and leaders: A graduate program perspective. Charlotte, NC: Information Age Publishing.

Council for the Advancement of Higher Education Programs. (2015). A commitment to research quality and professional practice: Voluntary guidelines for higher education administration preparation programs at the doctoral degree level [working draft]. Las Vegas, NV. Available at http://www.ashe.ws/images/CAHEP\%20ProposedDocGuidelinesMay2015.pdf 
Crosson, P. H., \& Nelson, G. M. (1986). A profile of higher education doctoral programs. Review of Higher Education, 9, 335-357.

Dill, D. D., \& Morrison, J. L. (1985). Ed.D. and Ph.D. research training in the field of higher education. A survey and proposal. Review of Higher Education, 8, 169-186.

Dressel, P. L., \& Meyhew, L. B. (1974). Higher education as a field of study: The emergence of a profession. San Francisco: Jossey-Bass.

Favero, M. D. (2006). An examination of the relationship between academic discipline and cognitive complexity in academic deans' administrative behavior. Research in Higher Education, 47(3), 281-315.

Freeman, S., Jr. (2012). The future of higher education preparation: Implications for policy and practice. Journal of Education Policy, 1, 1-8.

Freeman, S., Jr., \& Kochan, F. (2014). Towards a theoretical framework for the doctorate in higher education administration. In S. Freeman, Jr., L. Hagedorn, L. Goodchild, \& D. A. Wright (Eds), Advancing higher education as a field of study: In quest of doctoral degree guidelines - Commemorating 120 years of excellence (pp. 145-167). Sterling, VA: Stylus Publishing.

Goodchild, L. F. (1991). Higher education as a field of study: Its origins, programs, and purpose, 18931960. New Directions for Higher Education, 76, 15-32.

Goodchild, L. F. (1996). G. Stanley Hall and the study of higher education. The Review of Higher Education, 20(1), 69-99.

Goodchild, L. F. (2014). Higher education as a field of study: Its history, degree programs, associations, and national guidelines. In S. Freeman, Jr., L. Hagedorn, L. Goodchild, \& D. A. Wright (Eds). Advancing higher education as a field of study: In quest of doctoral degree guidelines - Commemorating 120 years of excellence (pp. 13-50). Sterling, VA: Stylus Publishing.

Harris, M. S. (2007). The current status of higher education programs: Findings and implications. In D. W. Wright \& T. Miller (Eds.), Training higher education policy marers and leaders: A graduate program perspective (pp. 33-42) Charlotte, NC: Information Age Publishing.

Haynes, L. J. (1991). Basic knowledge and competency needs: Perspectives on the content needs of higher education administration programs. The University of Minnesota.

Hendrickson, R. (2014). The core knowledge of higher education. In S. Freeman, Jr., L. Hagedorn, L. Goodchild, \& D. Wright (Eds.), Advancing higher education as a field of study: In quest of doctoral degree guidelines - Commemorating 120 years of excellence (pp. 229-240). Sterling, VA: Stylus Publishing.

Hofsteader, R. (1960). The age of reform. New York: Random House.

Hyle, A., \& Goodchild, L. F. (2014). Contemporary conditions of higher education programs in the United States and Canada: An initial 2012 report. In S. Freeman, Jr., L. Hagedorn, L. Goodchild, \& D. Wright (Eds.), Advancing higher education as a field of study: In quest of doctoral degree guidelines - Commemorating 120 years of excellence (pp. 51-75).

Kuhn, T. (1962). The structure of scientific revolutions. Chicago: University of Chicago Press.

Lattuca, L. R., \& Stark, J. S. (2011). Shaping the college curriculum: Academic plans in action. Boston: Allyn and Bacon.

Lipka, S. (2014). Proposed federal rules would raise oversight of campus assault. The Chronicle of Higher Education. Retrieved from http://chronicle.com/blogs/ticker/proposed-federal-rules-increase-oversightof-campus-sexual-assault/80183

Miller, M. T., \& Nelson, G. (1993). Graduate programs in the study of higher education selected syllabi. Tuscaloosa, AL: University of Alabama. ED363238.

Perry, J. A. (2015). The Carnegie Project on the Education Doctorate. Change: The Magazine of Higher Learning, 47(3), 56-61. 
Pope, R. L., Reynolds, A. L., \& Mueller, J. A. (2004). Multicultural competence in student affairs. San Francisco, CA: Jossey-Bass.

Rumbley, L. E., Altbach, P. G., Stanfield, D. A., Shimmi, Y., de Gayardon, A., \& Chan, R. Y. (Eds.). (2014). Higher education: A worldwide inventory - Research centers, academic programs, and journals and publications (3rd ed.). Science Management series. Boston and Bonn, Germany: Center for International Higher Education, Boston College and Lemmens Media.

Smart, J. C., \& Elton, C. F. (1982). Validation of the Biglan model. Research in Higher Education, 17(3), $213-229$.

Townsend, B. K. (1990). Doctoral study in the field of higher education. In J. C. Smart Ed). Higher education: Handbook of theory and research, VI (pp. 161-199). New York: Agathon Press.

Uzoigwe, C. N. (1982). A model for establishing a higher education administration degree program at a Nigerian university. University of Toledo, Ohio.

Valerin, M. P. (2011). Comparative analysis of 105 higher education doctoral programs in the United States. University of North Texas, Denton, Texas. (Unpublished Dissertation).

Van Horn, P., Green, K., \& Martinmussen, M. (2009). Survey response rates and survey: Administration in counseling and clinical psychology: A meta-analysis. Educational and Psychological Measurement, 69(3), 389-403.

Wang, X. (2002). A study of the curriculum structure and content of doctoral programs in higher education in the People's Republic of China. Baylor University, Waco, Texas.

Wright, D. (2007). Progress in the development of higher education as a specialized field of study. In D. W. Wright \& T. Miller (Eds.), Training higher education policy makers and leaders: A graduate program perspective. Charlotte, NC: Information Age Publishing.

Wright, D. W. \& Miller, T. (Eds.). (2007). Training higher education policy makers and leaders: A graduate program perspective. Charlotte, NC: Information Age Publishing.

\section{Biographies}

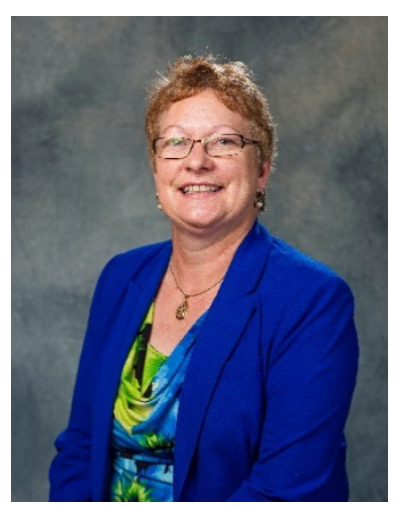

Karen Aldred Card, Ph.D. is Interim Chair of Educational Administration at the University of South Dakota. Dr. Card received her Ph.D from The Ohio State University in Educational Policy and Leadership. She received her Masters degree in Student Personnel from Bowling Green State University. Dr. Card research focuses on college administration, student affairs, and college teaching. She currently serves as the Pre-Conference Chair and Syllabus Project Chair for the Council for the Advancement of Higher Education Programs. Additionally, she is the coordinator of the Association for the Study of Higher Education's Higher Education Directory that catalogues over 150 higher education programs throughout the United States and Canada. 


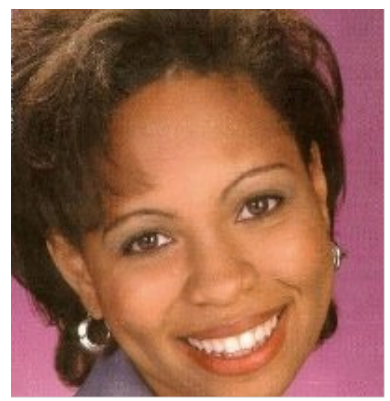

Crystal R. Chambers is associate professor and program coordinator of the doctoral program in higher education leadership in the Higher, Adult, \& Counselor Education Department at East Carolina University in Greenville, North Carolina. Her research focuses on the impact of race and gender on college student access and experiences, faculty employment, and equality of opportunity in public higher education systems. Chambers is an inaugural year participant of the Council for the Advancement of Higher Education Program's Early Career Workshop and has been an active participant in CAHEP since 2008. She is the associate editor-in-chief of The Journal for the Study of Postsecondary and Tertiary Education.

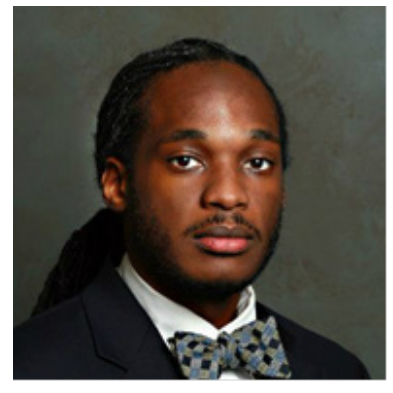

Sydney Freeman, Jr., is associate professor of higher education at the University of Idaho. He is a former National Holmes Scholar, a certified faculty developer through the Learning Resources Network, and an affiliate of the University of Pennsylvania's Center for Minority Serving Institutions. His research investigates the challenges facing higher education administration programs, specifically, higher education as a field of study and the university presidency. Dr. Freeman has published numerous journal articles and is the lead editor (with Linda Serra Hagedorn, Lester F. Goodchild, and Dianne A. Wright) of $A d-$ vancing Higher Education as a Field of Study: In Quest of Doctoral Degree Guidelines (Stylus Publishing, 2014). He also was recently named to the Board of Directors of the American Association of University Administrators and was honored with the "2015 Emergent Leader of the Year" award by the same professional society. He is editor-in-chief of The Journal for the Study of Postsecondary and Tertiary Education. 